\title{
O protagonismo indígena na fronteira amazônica
}

Glória Kok

A PÓs Ouro vermelbo: a conquista dos indios brasileiros (Red gold. The conquest of the Brazilian indians, 1978), traduzido por Carlos Eugênio Marcondes de Moura (Edusp, 2007) e antes do livro Die if you must. Brazilian indians in the Twentieth Century (2003), alinhado aos trabalhos de Rondon, Darcy Ribeiro e Orlando Villas-Boas, ainda inédito no Brasil, o historiador e ex-diretor da Royal Geographical Society de Londres, John Hemming, escreveu Fronteira amazônica: a derrota dos indios brasileiros (Amazon Frontier, 1987), recém-lançado pela Edusp, em tradução de Antonio de Pádua Danesi.

No primeiro livro, Ouro vermelho, Hemming traçou uma abrangente narrativa da história dos índios na colônia portuguesa, num arco que se estende da Carta de Pero Vaz de Caminha de 1500, até a década de 1760, ocasião em que cerca de seiscentos jesuítas são expulsos dos colégios e aldeamentos, o que assinala um divisor de águas na história dos índios. Com base nos textos de cronistas, missionários, aventureiros e estudiosos, o autor descreve os contatos entre nativos e europeus permeados, na maioria das vezes, pela violência. As populações nativas foram vítimas das doenças europeias, da escravidão e da destribalização, resultando em um agudo declínio populacional. Daí as frequentes adjetivações que quase anunciam o "fim" das populações indígenas: numa passagem do prefácio, o autor enfatiza que os índios foram "aniquilados" e "dizimados" pe- las doenças, que a coragem e as táticas guerreiras foram "anuladas", que "quase têm sido condenados à extinção" e hoje "estão reduzidos a uma minoria patética..." (p.21).

No segundo volume da trilogia, Fronteira amazônica, Hemming estuda os viajantes, cientistas, artistas e antropólogos que visitaram os índios brasileiros, para continuar a história dos índios da década de 1760, ocasião da expulsão dos jesuítas e da implantação do Diretório, até 1910, ano em que é aprovado o Serviço de Proteção ao Índio. Dividido em quatro partes que seguem uma ordem cronológica, o livro apresenta um caleidoscópio dos grupos indígenas que viviam nos territórios fronteiriços do império português e seus conflitos com os colonos.

Na primeira, “O Diretório”, o autor analisa a legislação indigenista elaborada em meados do século XVIII para os índios do Estado do Maranhão e GrãoPará, pelo primeiro-ministro de Portugal, Sebastião José de Carvalho e Melo, o futuro Marquês de Pombal. Em 1757, um decreto libertou as aldeias indígenas do controle missionário, transferindo aos "diretores" brancos essa responsabilidade. A medida visava atingir a Companhia de Jesus, a ordem mais bem-sucedida da Colônia, e seus membros, que dispunham da mão de obra de mais de sessenta aldeias disputada pelos colonos. O sistema do Diretório visava integrar os índios à sociedade portuguesa, mobilizando-os por meio do trabalho. Para isso, muitas medidas tornaram-se obrigatórias, como 


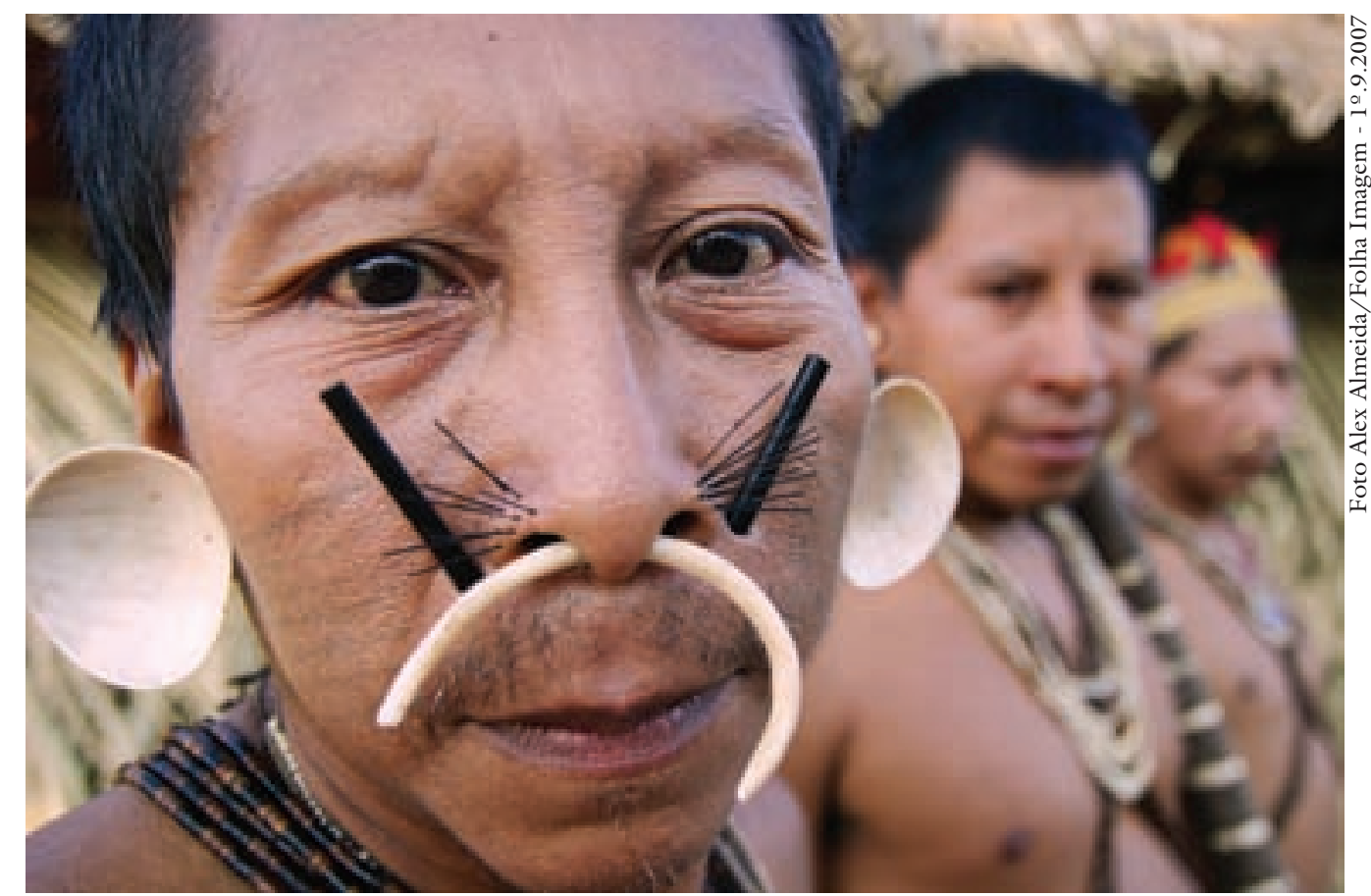

Índios da etnia dos Matis, que habitam o Vale do Javari, sudoeste do Estado do Amazonas.

a língua portuguesa, viver em casas separadas, o uso de roupas sem ornamento decorativo e o incentivo de casamentos entre brancos e índios.

As aldeias do Diretório cultivavam produtos básicos (mandioca, arroz, milho, cacau, café e algodão) e coletavam as "drogas" do sertão (salsaparrilha, cravo, castanhas-do-pará, alcatrão, seivas de andiroba, da copaíba e da sumaúma, ipecacuanha), para abastecer o crescente mercado colonial. Forneciam também mão de obra para os serviços públicos: estaleiros, expedições de corte de madeira, construções de fortalezas, remadura e transporte de barcos. Pela regra, os índios de treze a sessenta anos estavam habilitados para trabalhar e viviam sob um regime de trabalho excessivo e brutal. O jesuíta João Daniel testemunha a violência dos colonos e acentua que é "louvável o castigo de só quarenta açoites, como costumavam os missionários" (p.83). O pagamento, se houvesse, era feito com roupa ordinária de algodão.

O Diretório vingou nas 66 aldeias indígenas do Maranhão e do Amazonas durante quarenta anos, período em que "o número de índios administrados no Pará e na Amazônia caiu em mais de um terço, de trinta mil em 1757 para nove mil em 1798" (p.97).

A partir de 1758, o Diretório se estendeu da Amazônia para outras regiões do Brasil. Em Goiás, as autoridades coloniais formaram cinco aldeias para servir de modelo de "civilização" aos índios xavantes, caiapós e javaés, que foram se despovoando até cair em ruínas. Foi então que a índia caiapó Damiana da Cunha, convertida ao cristianismo, chefiou expedições para atrair os caiapós. Nessas ocasiões, diz o documento, "põe-se nua, pinta-se e sai ao campo, e conduz os índios como the parece" (p.123). Apesar de ter deslocado numerosos caiapós, as aldeias não tardaram a definhar.

Muitos grupos indígenas, entretanto, 
não aceitaram pacificamente $\mathrm{o}$ avanço da colonização portuguesa em seus territórios. Nos rios Amazonas, Solimões e Negro, os muras desestabilizaram quaisquer tentativas de estabelecimentos portugueses na região até o final do século XVIII. Hábeis guerreiros surpreendiam os navegadores com ataques e emboscadas fulminantes. Outra tribo aguerrida era a dos mundurucus. Para combatê-los, o governador João Pereira Caldas declarou guerra em 1778. Alguns anos depois, tanto os muras como os mundurucus se renderam e foram viver em aldeias, só que cada grupo teve um destino bem diferente. Nas lutas de resistência indígena, destacaram-se, ainda, os botocudos, que viviam nos vales dos rios Jequitinhonha, Mucuri e Doce, e os caingangues (coroados), que habitavam São Paulo e o atual Estado do Paraná. Ambos foram duramente combatidos por meio de um decreto régio de 1808 que proclamou "guerra ofensiva" e legitimou a escravização dos prisioneiros de guerra.

O Diretório foi abolido em 1798, deixando um legado de aldeias decadentes, em razão das revoltas contra o regime de trabalho, das epidemias e das fugas dos índios, porque, comenta o autor, "preferiam internar-se nas selvas a viver entre os colonos 'civilizados'. Tribo após tribo afastava-se aos poucos das fronteiras coloniais" (p.201).

$\mathrm{Na}$ segunda parte, "Independência", o autor examina os povos indígenas no curso do Império brasileiro. Na transição entre a colônia portuguesa e o império, Guido Marlière, alferes do exército português, traçou um plano estratégico para a "pacificação" e a "civilização" dos índios no Brasil. Ajudado pelos coroados e coropós do Paraíba, Marlière subjugou os puris, que foram aldeados em 1819. O botocudo Pocrane, que adotou o nome cristão de Guido Pocrane, serviu-lhe de intérprete e recebeu, como recompensa, uma fazenda de gado e roupas europeias. Nomeado diretor-geral dos índios de Minas Gerais em 1824, controlou uma população de 4.300 nativos, para os quais distribuiu ferramentas para os trabalhos agrícolas e solicitou a presença de missionários. Mas doenças e a subnutrição abateram-se sobre os índios aldeados, comprometendo irremediavelmente o seu plano.

Durante o Império, a principal legislação indigenista é conhecida como $R e^{-}$ gimento das Missões, decretada em 1845. Aparentemente, acenava com cláusulas favoráveis aos índios: a promessa de demarcação dos territórios das tribos em aldeias de usufruto coletivo, a proibição de guerras e bandeiras contra os índios, a proteção às atividades indígenas. No entanto, a verdadeira pretensão do Regimento era aculturar os índios, transformando-os em súditos do imperador, sujeitá-los a trabalhos forçados em obras públicas e conceder ao diretor o direito de dispor sobre as terras indígenas, além de estabelecer dois sistemas de administração contraditórios: o dos diretores leigos e o dos missionários. Dois anos depois, as aldeias estavam sendo invadidas pelos colonos e as terras, espoliadas. Esse processo de expropriação foi fomentado com a Lei das Terras de 1850, que reivindicava para o Estado as terras devolutas. Para o antropólogo Carlos Moreira Neto, a legislação imperial negava aos índios "O direito de aspirar à autonomia cultural ou política ou a possuir as terras que tradicionalmente ocuparam" (p.237).

Nas fronteiras, as rivalidades entre colonos e numerosas tribos guerreiras acirraram-se no século XIX. No fronteira do 


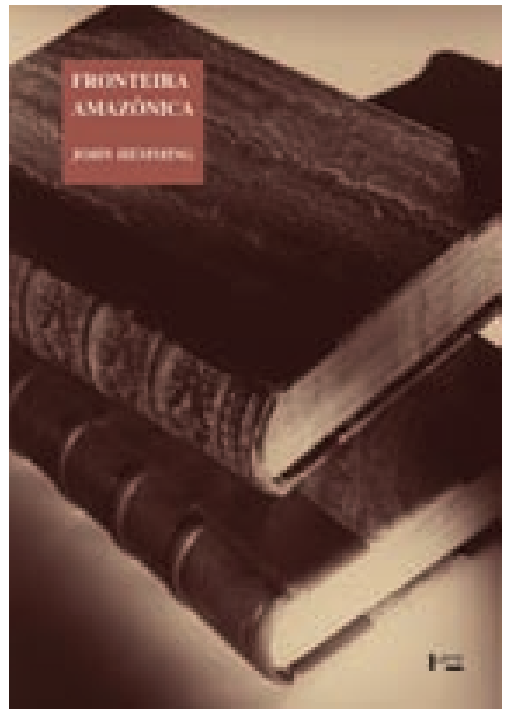

HEMMING, J. Fronteira amazônica: a derrota dos índios brasileiros. Trad. Antonio de Pádua Danesi. São Paulo: Edusp, 2009. 709p.

Maranhão, destacaram-se os gamelas, os guajajaras e os grupos timbiras do leste; na fronteira Tocantins-Araguaia, os apinajés, os carajás, os xavantes, os xerentes e os canoeiros; na fronteira de Goiás a Cuiabá, os bororos. Contra esses grupos guerreiros, os colonos organizaram expedições punitivas, construíram fortes e valeram-se das rivalidades intertribais, aliando-se com certos grupos nativos. Os mundurucus, por exemplo, permaneceram fiéis, depois de 1800, ao governo brasileiro e lutaram contra vários grupos indígenas, entre os quais os muras.

As tensões na Amazônia culminaram com a revolta da Cabanagem ("cabanos" - migrantes que viviam em cabanas nos brejos de Belém ou nas matas do Amazonas) no ano de 1835. Tapuios (índios destribalizados), índios, brancos pobres e mestiços do Pará uniram-se contra os brancos, destruíram fazendas, mataram colonos e declararam o Rio Negro uma província independente do Pará. Apesar da repressão, os revoltosos fugiram ao controle do governo imperial. A Cabanagem espalhou-se pela rede de rios amazônicos, criando bolsões de resistência, como o território dos muras. Com a ajuda dos mundurucus, as revoltas foram esmagadas e os cabanos se renderam. Segundo o cacique Joaquim José Pereira, dos mundurucus do Rio Abacaxis, "seus parentes prestaram valiosíssimos serviços contra a revolução" (p.302). A revolta da Cabanagem fez trinta mil mortos, além de propiciar a formação de numerosos mocambos na região.

A terceira parte, "Amazônia: surto da borracha", trata do impacto do surto da borracha para os povos nativos. Conhecida pelos omáguas do Solimões desde o período pré-colonial, a borracha da Amazônia passou a atender à demanda mundial a partir da década de 1850 , inicialmente extraída nos rios Xingu e Tapajós e, depois, nos rios Madeira, Purus e Juruá. Os barões empregavam tapuios e índios como seringueiros em regime de escravidão por dívida. No contexto do surto da borracha, a situação dos grupos indígenas variou enormemente. Algumas tribos aliadas do governo imperial enriqueceram com o comércio da borracha, enquanto outras lutaram contra a presença dos seringueiros, padecendo com as expedições punitivas e a escravização. A tribo que mais sofreu com o tráfico de escravos, segundo o autor, foi a dos miranhas do Japurá. Para os seringueiros, "Os índios são bichos, e como tais devem ser tratados" (p.380).

Na última parte, "1840-1910: missionários, antropólogos e resistência indígena", Hemming analisa a presença dos missionários entre os grupos indígenas 
das fronteiras e a formação de novas missões. O livro se encerra com as explorações de Cândido Rondon que levaram à criação do Serviço de Proteção ao Índio, aprovado pelo presidente Nilo Peçanha em 1910, cujo objetivo principal era dar proteção às terras indígena e garantir a devolução aos índios das terras roubadas pelos colonos. Inaugurava-se, assim, uma nova era para os índios brasileiros.

Em Fronteira amazônica, Hemming adota uma ligeira mudança de perspectiva em relação ao volume anterior, porque valoriza, progressivamente, o protagonismo indígena. Vale comentar que a tradução apresenta alguns deslizes, como a mudança de gênero do antropólogo Robin Wright. As raras vozes indígenas presentes no volume deixam entrever a posição de alguns índios diante da conquista, deslocando o olhar do leitor. Uma é a do chefe Carô dos carajás xambioás, morador do Araguaia, que assevera: “Presídio, não, não quero. - Padre não, turi (cristão), não, boi não, cavalo não" (p.484). A outra é a de Rosa Bororo, que, às vésperas de sua morte, aconselha o filho: "não confies nos brancos. São homens que manejam o raio, que vivem sem pátria, que vagam para satisfazer sua sede de ouro e nos acarinham quando de nós têm necessidade, porque a terra em que pisam, e os campos e os rios que assaltam são nossos [...] atingida a meta, são falsos e traidores...” (p.504)

Glória Kok faz atualmente pós-doutorado junto ao Departamento de Antropologia da Unicamp. É autora de Os vivose os mortos na América portuguesa: da antropofagia à água do batismo (2001), O sertão itinerante. Expedições da capitania de São Paulo no século XVIII (2004), entre outras publicações.

@ - kokmartins@uol.com.br 